\title{
As the Pilot Leaves the Ship: . An Interview with H.L. Wesseling
}

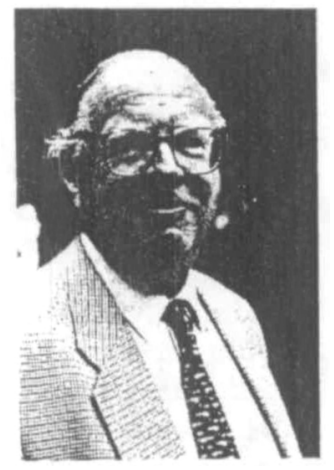

Last spring, Henk Wesseling, who has almost continuously been at the helm of the Centre since its foundation, was appointed director of the prestigious NLAS, the Netherlands Institute for Advanced Study, at the wooded village of Wassenaar, near The Hague. Therefore, Professor Wesseling had to abandon most of his tasks at Leiden University, such as the directorship of the Centre. This would seem a splendid occasion to usher our former director into the hall of fame of Itinerario interviewees.

Itinerario: You started out as a historian of modern France. Why did you take the initiative to embark upon the history of European expansion?

Wesseling: That is a rather long story, full of coincidence. First of all there is the matter of how I became a professional historian at all. For this we have to go back to the year 1966. At that time I was a teacher at a lyceum, a grammar school. During the vacations I worked on my dissertation (there was no graduate school or anything of that kind then). In January or so I got a telephone call from Professor Bertus Schaper, who was my supervisor. He asked me if I would accept an offer to become a lecturer in Leiden, which I did. Of course I asked: 'What do I have to do for my job?' I was then a teacher, working quite hard for my money, teaching thirty hours a week. Schaper said: 'Well, there isn't really anything to do yet, but maybe after the summer you could teach a seminar for freshmen.' This was quite a different life as compared to being a teacher, and it gave me time for my dissertation, which I finished two years later, in early 1968. It took some 
time before it was published, because of delays with the financing, but I finally got my degree in early 1969.

I received a cum laude, which was then rather exceptional, and Schaper came and said he would ask for some kind of promotion for me. Not a higher position, but a raise of salary, some fifty guilders a month or so. I was not really very anxious to get that because it was a very small amount of money, but it was very kind of him to suggest such a thing. Then for months I heard nothing about it, until he came to see me again, looking not too happy with himself. He had discussed this raise of salary with his colleagues, and they had strongly discouraged him to go ahead with it. Because, as they had told him, other lecturers might get jealous! That puzzled me a great deal. What was the reason for this? Why would people be jealous when research was being rewarded? Apparently it was because in those days - and this is relevant to the founding of the Centre - research was of no interest whatsoever to the university administration. They could not care less! Every now and then they would ask how your book was coming along, and that was it. I found that very strange.

In September 1972 the Netherlands Institute for Advanced Study (NIAS) was opened and I got an invitation (they had to find people on short notice), but I could not come since I had also received a stipend from ZWO [the Dutch Organization for Scientific Research]. Ten or twelve fellowships were offered each year, mostly to physicists, who went to America. One or two went to people from the humanities and social sciences. I wanted to go to France, my dissertation being on French history, and I also was curious about French academic life, about the Annales historians who had become very famous in those days. I got the money and so I went. I did not do any of the things I had written on my application form: that I was going to work on a book on the intellectual origins of fascism, a subject which I was and still am very interested in. There were several reasons why I decided not to go along with that. First of all, I discovered that Zeev Sternhell, who in the meantime has become a famous historian in this particular field, was already doing that and was actually working in Paris on this topic, as well as the American historian Robert Soucy, whose last work on this topic came out recently. And then I met Henri Brunschwig in a seminar. I had written to him to ask if he would receive me as a chercheur confirmé, which he did.

Through Schaper, I had already developed an interest in the subject of Imperialism. In 1968-1969, the time of many democratic reforms, Schaper took up this idea to get his staff to come together in collective research seminars. My colleague Hans Jacobs would do German imperialism, I would do French imperialism, Carla Musterd would do Russian imperialism, I suppose he himself would do British imperialism, and so on. I had done some reading on French imperialism. Henri Baudet, whom I knew, was kind enough to write a letter of introduction for me, and that is how I met Henri Brunschwig. 
The seminar was an eye-opener for me: I discovered that there it was not the professor who spent his time preparing a course, but it was the students who were actually helping the professor to get his research done! They went into the archives and did all kinds of research and then he collected it all and wrote his books. I thought, my God, this is a much cleverer system! You should remember that in Leiden the manner of teaching was not efficient at all. Students could decide themselves on which books they wanted to be examined. So teachers sometimes had to read for weeks on end in order to be able to take the examination. I found that an extremely silly system. The system they had over there at Paris was much better for research, it also was much more productive. Something else that I ran into at Paris, and that shaped my opinion on university research and teaching, was the Chronique de recherche, a seminar run by Pierre Goubert, where he invited all sorts of people finishing their doctorats. Most of these scholars were in their thirties or forties. At those sessions one really felt in touch with all the new things from all directions. I found that very refreshing indeed.

When I came back to Leiden I had done research for an article on the Dutch colonial model in French colonial theory, something on the Dutch in Africa, and so on. Not really very much. But I had learned a lot. And then in 1973, I was offered the chair in Contemporary History. I think it was then that I started to think about introducing some of these elements to Leiden. Following Pierre Goubert's example, Ivo Schöffer and I set up the so-called Kroniekcollege, which was very successful and attracted some very good students.

Itinerario: But your thesis was not about imperialism. It was about French generals.'

Wesseling: Well, actually not only about generals. It is about the idea of war in France. It is a very traditional 'history of ideas' type of book. I still remember what Jean Stengers said when I first gave a lecture in Brussels for his students. He had read the book and said it was so typical of the difference between the Dutch and Belgian universities that in the Netherlands such a book could serve as a dissertation. He meant this in a very kind way: not that it was rubbish, but that it was so personal and essayistic. The Belgians have a much stronger tradition of artisanat. It is indeed a rather personal book on a topic that interested me a great deal. Why was there written so much on German militarism, and so little on French militarism? Why were the French, some French at least, so eager to go to war? How was it possible that so soon after the deep crisis of the Dreyfus Affair the French army was in such a good shape and spirit?

Itinerario: People like Bugeaud have also played a role in French militarism, is it not?

Wesseling: Sure, there are some generals in the book. But there are many other 'scenes' covered by it as well. I deal with poets, novelists, journalists, literary critics and so on. I wanted to know why it was possible for people 
to believe that war was such a wonderful thing. We normally associate this with German militarism: frischer, fröhlicher Krieg and so on. But I found as many disturbing sentiments in French literature, which have never been discussed to any extent in the literature on the origins of the First World War. I was interested in the question of war, and why so many people were in favour of the army. There are some aspects of colonialism in it, but it is mainly about patriotism, nationalism, and militarism. Many of the people I dealt with in my dissertation died in battle, often in the first months of the First World War.

But to come back to the year in Paris and another 'discovery': I had always been very impressed by all those professors who had on their stationary 'Centre de Recherche' of such and so. Now, being in Paris, whenever I weint to visit such a 'centre' there would be a secretary telling me the professor was not there at the moment. Next door would be another 'centre', again with the same secretary, again saying the professor was not there, and so on. Obviously, these centres were only a façade! So I never was afraid of calling our Centre a 'centre' before it really had become one, although I think it was Pieter Emmer who came up with that name.

Itinerario: The Centre was meant to be a research centre, rather than a new beginning in teaching, or was it meant to be both?

Wesseling: No, it was to become exclusively a research centre. The purpose I had in mind was to put research on the agenda. It is interesting to see that in the last ten years or so the pendulum has swung completely the other way, research getting all the attention. And now of course teaching is coming back as an issue. Well, I suppose that is how it is at universities.

Itinerario: You wanted to bring together historians of Western history with those of non-Western history. Would you say, twenty years later, that your goal has been attained?

Wesseling: I had some basic objectives. First of all, I did not believe in some general theory about European expansion. Nor did I believe that one should do only monographs, only case-studies. I thought that comparative studies could make a good compromise between an approach that would be too theoretical and abstract on the one hand and one that would be too pragmatic on the other. I strongly believe in comparative studies, in looking whether studies on other countries could also be applied to the Dutch situation, and in collective projects. So, if I had a strategy, it was like Napoleon's, who said: 'On s'engage et puis on voit'. Not a bad example for strategy, by the way, Napoleon.

Itinerario: Did you expect the curriculum of European expansion as a comparative study would grow towards independence, that it would get its own chair?

Wesseling: I thought right from the beginning that the solution was not to have one professor for the whole history of European expansion and the reactions to it, because it is impossible to have an overview of such an enormous field. The Leiden approach was to be a collective one, to bring 
together people who were interested in European expansion in an enlightened way and people who were interested in national and regional histories of the overseas world with an open eye for world history. And I think we were not wholly unsuccessful. In fact, the human material was already there: Heesterman, Zürcher, Bruijn, Schöffer, and others. But the point was to get them to do something collectively. If I would be asked if this has been totally satisfactory, I would say no, not totally, because everybody has his own abilities, ambitions, interests, and responsibilities. You cannot expect them to give up their own activities in order to work collectively on the history of European expansion. I have never done that myself. I have never been a 'specialist' of anything.

Still, as far as I am concerned, European expansion is a fascinating subject. It is one of the two possibilities to think on a world-historical level. One is macro-sociology, which means looking at a certain problem in various different parts of the world, and the other one is to study the worldhistorical process. And in that the history of European expansion is unique. It has not always been there, and one day it will not be there any more. That makes it a historical process. The cultural, mental, and economic - not political - unification of the world is a historical process which has taken place in time. You can ask what its origins, development, and periodisation have been. And that, fundamentally, is my approach.

Itinerario: Rather than collecting as many $\mathrm{PhD}$ students as possible, you have been more interested in joining organisations, or setting them up yourself. You are not a typical educationalist.

Wesseling: As far as graduate students are concerned, I may not be much of an educationalist, but you also have to understand the situation at Leiden. Leiden is the only university with a chair for the History of the Fatherland (Vaderlandse Geschiedenis). And, like in every country, eighty per cent of the dissertations are about national history. So, traditionally research in the classical sense has always been done in the 'Fatherlandic' History section, while the 'general' historians did, so to say, the rest. But I must also admit that $I$ have never been very sad about not having too many $\mathrm{PhD}$ students. It would be absurd if they would all come to me, simply because I was in charge of European expansion, in stead of going to the person that is most specialized in their specific field of research, be it Africa, Indonesia or whatever. Moreover, I am not particularly gifted when it comes to working with $\mathrm{PhD}$ students. I may be a little bit selfish in that respect.

Itinerario: Yet, now you are the director of NIAS, the Netherlands Institute for Advanced Study, an international research institute. So you are interested in making research possible, but in a more international framework.

Wesseling: That is true. With the Centre I have always been interested in an international approach. There have been many international projects and I am also active in the European Science Foundation and in the Academia Europaea. But this appointment came as a complete surprise. 
Itinerario: Moving on to your written work, what is essential for you about the impact of European expansion?

Wesseling: The European expansion is unique. I do not believe that there was a world economy in 1500, but there definitely is one now. Europe had not always been the more developed continent, but it did become so after 1500. And that would not have been possible without (i) the industrial revolution, and (ii) the process which we now call the expansion of Europe. That is why I say it is an important and unique world-historical event. It is unique in two respects. It is the only expansion that took place on a global scale and the only one that led to a form of universal civilization. This universality can be divided into three levels. First there is the material level: the consumer products that are more or less the same over the world (jeans, Coca-Cola, hamburgers, etcetera). Then there is the cultural level: mass culture (music, soap opera, television). Maybe it is not European, but western; we cannot really distinguish western from European. And finally, there is the ideological level: the United Nations, human rights, Marxism, they are all typically western notions.

Itinerario: Why was the expansion of France different from European expansion in general?

Wesseling: I would say it was the other way around, that it was the British expansion that was atypical. Because it was unique in combining the expansion of people, the expansion of values, the expansion of the economy, and finally the political expansion. French, German, Italian or Dutch imperialism did not combine all these elements. You can only compare the position of Victorian Britain to that of the US after the Second World War. So I think that late Victorian Britain may be compared to Clintonian America.

Itinerario: What is your position in the debate about whether or not the Netherlands were an imperialist nation in the late nineteenth century?

Wesseling: It is obvious that at a certain point in time there existed a nationalist-imperialist mood in the Netherlands. But there never was an imperialist policy, because that was against the realities of power. The Dutch government wanted to round off its possessions in the East Indies. Deals were made with other powers and indigenous rulers in order to straighten out the borders. But that was because it was necessary, not because it was desired in the first place.

Itinerario: The urge of the central government to establish its rule over its territories could in that period also be found in countries like the US, Argentina, and Chile. It was universal, not typically colonial.

Wesseling: Yes, so the question is why did it happen at that particular time? Dutch 'Imperialism' was a reaction, it was not a spontaneous process. Competition from other nations brought about the urge to make sure no matters were left open. It was a reaction to the imperialism of others. If you maintain that no matter what caused it, the Netherlands were an imperialist nation, I say: That is right, but if every power had had the same 
policy as the Dutch - which was to stay within the territory that had been recognized by means of treaties by the other powers as one's sphere of influence - there would not have been an Age of Imperialism at all!

Itinerario: You have written a book about European expansion in Africa between 1880 and $1914 .^{2}$ What, would you say, is new about your book?

Wesseling: Yes, why indeed did I write it? Well, essentially because there was no such book yet. I was very surprised about that observation. So when I started writing I thought it was rather ambitious and I wondered if I would ever be able to complete it. What I had in mind then was more a sort of textbook. As I was in the process of writing, however, this approach changed, and the work became more one of story-telling. It was, by the way, immensely difficult to find a practical vantage point from which to tell the story. Obviously it was not possible to tell the story year by year, nor to look at every colonial power or area separately. Finally I decided on a regional approach, but basing every chapter on one particular episode; so the story about Tunisia and Egypt was concentrated in 1881-1882, the one about the Congo in 18841885, etcetera. The development over time became the main structure and was combined with a regional approach.

Itinerario: The book also contains very vivid descriptions of people.

Wesseling: I have tried to tell the story in terms of people and their motives. That is one form of analysis. The other is to look at impersonal forces. I have dealt with that in the conclusion. But the book itself is essentially about motives and decisions, and when dealing with that, you will also have to explain something about who the people were that made the decisions. They were very extraordinary people, mostly, and during the writing I realized how absurd much of the story was.

Itinerario: Would you argue that the period you describe lays at the root of the present disastrous situation in Africa?

Wesseling: How can we know what Africa would have looked like if things would have happened differently? In the period I describe the colonial states were formed, and they have survived decolonization. Nation building in itself is not an impossible process. It worked in Europe, and so far it has worked in Asia, for example in India and Indonesia. That it functions badly in Africa has to do with the economic situation, with the short duration of the colonial period, with bad government. And now what should be done? I do not know. Maybe the solution would be federalism, lessening the influence of the nation state, which in Europe also has lost its monopoly of power.

Itinerario: Has the expansion of Europe ended? In what stage are we at this moment?

Wesseling: Two movements are currently being perceived by Europe as possibly dangerous: the economic situation and the challenge of Islam. Will Europe be able to stay in the economic race with the US and Asia? This is a great challenge. But Asia is not being perceived as a danger to European civilization. The other movement, however, is Islam, which is 
being perceived as a cultural danger, but not as an economic rival. That is a very interesting dichotomy. There is no easy answer to the question whether the West has won and history is over. There is no need to be overoptimistic. There is no 'end of history' and I, for one, never thought the fall of the Berlin Wall would end the chances on war forever. On the contrary.

Itinerario: Finally, you are a historian who is very present in Dutch public life. How do people react to what you write?

Wesseling: I frankly do not know. Nor am I very interested. I write for fun.

Notes

1 H.L. Wesseling, Soldaat en Krijger: Franse Opuattingen over Leger en Oorlog, 1905-1914 ('Soldier and Warrior: French Opinions on Army and War, 1905-1914'), (Leiden 1969; 2nd ed. Amsterdam 1988).

2 H.L. Wesseling, Verdeel en Heers: De Deling van Afrikn, 1880-1914 ('Divide and Rule: The Partition of Africa, 1880-1914'), (Amsterdam 1991). 